Research article

\title{
PROLIFERATION AND DIFFERENTIATION POTENTIAL OF CANINE SYNOVIAL FLUID CELLS
}

\author{
FRANCUSKI V Jelena ${ }^{1}$, DEBELJAK MARTAČIĆ Jasmina², RADOVANOVIĆ \\ Anita $^{1}$, ANDRIĆ Nenad ${ }^{1}$, SOURICE-PETIT Sophie ${ }^{3}$, GUICHEUX Jerome ${ }^{3}$, \\ MOJSILOVIĆ Slavko ${ }^{2}$, KOVAČEVIĆ FILIPOVIĆ Milica ${ }^{1 *}$
}

\footnotetext{
${ }^{1}$ Faculty of Veterinary Medicine, University of Belgrade, Bul. Oslobođenja 18, 11000 Belgrade, Serbia;

${ }^{2}$ Institute for Medical Research, University of Belgrade, Serbia, Bul. Oslobođenja 18, 11000 Belgrade, Serbia; ${ }^{3}$ INSERM U791, LIOAD, University of Nantes, France, 1-Place Alexis Ricordeau, 44042, Nantes Cedex 1, France
}

(Received $9^{\text {th }}$ July; Accepted $22^{\text {nd }}$ December 2014)

The aim of this study was to determine whether synovial fluid (SF) of dogs contains cells that have characteristics of MSCs and to describe their differentiation potential. SF adherent cells from 5 young German shepherd dogs (average $3.8 \pm 0.9$ years) were expanded $\left(37^{\circ} \mathrm{C}, 5 \% \mathrm{CO}_{2}\right.$, humidified atmosphere) three weeks before their phenotype was characterized by flow-cytometry for the presence of CD90 and CD34. Population doubling time (PDT), number of CFU-F and adipogenic, osteogenic and chondrogenic potentials have been determined in vitro. In early passages PTD was $31 \pm 10$ hours and expansion fold after 3 sub cultivations (9 days) theoretically could be $372 \pm 134$. At P1, $0.55 \pm 0.05 \%$ of SF cells had the ability to form CFU-F. Sixty-six percent of cells expressed CD90 and none of the cells expressed markers of hematopoietic cells. Oil Red O staining has shown accumulation of fat droplets in cells grown in adipogenic medium, while deposits of calcium in the osteogenic medium were evidenced with Alizarin red staining. SF cultured in hondrogenic and control medium in three-dimensional conditions formed a cartilage-like tissue. Alcian blue staining of pellets' slides have shown a significant amount of glycosaminoglycans (GAGs) and immunohistochemistry analysis documented collagen type II expression. The amount of GAGs in pellets grown in both conditions showed no difference. SF cells in vitro exhibited osteogenic, adipogenic and chondrogenic differentiation potentials, suggesting the presence of different mesenchymal progenitors. These results also demonstrated that SF cells have a spontaneous chondrogenic potential that should be further explored for possible tissue engineering protocols.

Key words: chondrogenesis, dog, mesenchymal stem cell, synovial fluid.

Corresponding author: e-mail: milkovac@yahoo.com 


\section{INTRODUCTION}

Normal synovial fluid (SF) is a hyaluronic acid rich, viscous liquid that protects diarthrodial joints and nourishes chondrocytes of avascular hyaline cartilage. Its volume in the knee joint varies between 0.1 to $1.0 \mathrm{~mL}$ and depends on dog size and weight. Normal SF contains approximately two to three million of cells per milliliter, predominantly mononuclear cells (lymphocytes, monocytes and sinoviocytes), while polymorphonuclear cells make up less than $10 \%$ of the total population. The main function of the SF leukocyte population is the immune surveillance of the joint tissue. Their transendothelial migration is similar in all tissues [1]. On the contratry, mechanism of steady state mobilization of synovial membrane (SM) synoviocytes into the SF has not been investigated. Also, the function of synoviocytes in the SF is just beginning to be defined and the first data obtained in rabbits [2,3] and some very recent experimental data in porcine, rats and rabbits point that SF cells could directly differentiate into chondrocytes and meniscal cells when hyaline cartilage or meniscal injury is provoked [2-6].

The normal SM is a fine structure consisting of a thin intimal layer of cells without a basal membrane, and subintimal tissue with scarce connective tissue cells, and blood and lymphatic vessels [1]. The intimal layer has two types of synoviocytes: type A that expresses markers of macrophages like CD163 and CD68 and type B that are fibroblasts expressing CD55, adapted to produce hyaluronic acid [1]. Although in situ examination does not reveal frequent cell divisions, it is well know that after trauma or during the course of osteoarthritis (OA) and rheumatoid arthritis (RA), proliferation of synoviocytes and other cells leads to the formation of pannus [7]. In several animal species and humans, multipotency and a large proliferative potential i.e. mesenchymal stem cell-like properties of SM and SF synoviocytes have been described [2-6, 8-11]. Moreover, chondrogenic potential of in vitro expanded SF synoviocytes has been proved to be more consistent than the same potential of bone marrow MSCs [12]. Synovial fluid cells could easily and repetitively be obtained without tissue trauma and consequent inflammation [13] making SF cells an interesting cell population for the management of cartilage repair and tissue engineering.

More than one fifth of dogs and two thirds of the aged human population are affected with different types of $\mathrm{OA}$ and consequently have cartilage injury, loss of chondrocytes and degradation of extracellular matrix i.e. collagen type II and glycosaminoglycans (GAGs). Hyaline cartilage has limited self-renewal potential and treatment options include surgery or the application of anti-inflammatory drugs and analgetics [14]. Neither of these treatments leads to cartilage regeneration nor permanent improvement of the initial damage. As described previously, some of SF cells also have mesenchymal stem cell (MSC) like properties and important regenerative potential [2-6]. Dogs are the model recommended by the Osteoarthritis Research Society International (OARSI) for investigation of OA pathogenesis [15]. Also, dogs are frequent patients for OA therapy. One of the suggested therapeutic 
modalities for OA is intra-articular application of non-differentiated MSCs or MSCs primed for chondrogenesis [16]. Data on proliferation and differentiation potential of canine synovial fluid cells are scarce and until present, only one article dealt with the chondrogenic potential of these cells in two dogs [17].

The aim of this study was to determine whether SF isolated from knee joints of adult young dogs without signs of $\mathrm{OA}$ or inflammation contains cells that have the characteristics of MSCs, and to describe their differentiation potential. The most important in vitro characteristic to be determined is the cartilage forming potential during the process of induced chondrogenesis.

\section{MATERIALS AND METHODS}

\section{Synovial fluid analyses and cell isolation}

Synovial fluid was aseptically aspirated from the knee stifle joint from 5 young German shepherd dogs (average $3.8 \pm 0.9$ years). In order to determine the total number of nucleated cells (TNCC), equal volumes of $500 \mathrm{U} / \mathrm{mL}$ hyaluronidase solution (Sigma) and SF samples were incubated at $37^{\circ} \mathrm{C}$ for 30 min. TNCC was determined using a hemocytometer with Trypan blue in acetic acid solution. Serum amyloid A was determined with ELISA kit (Tridelta, Irland).

Fresh SF samples were deposed over the whole surface in Petri dishes $\left(10 \mathrm{~cm}^{2}\right)$ in DMEM (Dulbecco's Modified Eagles Medium - Invitrogen) supplemented with 10\% FBS (MSC-Qualified FBS, Gibco), 1\% L-glutamine, and 1\% Pen/Strep solution (Gibco, Life Technologies, Grand Island, NY 14072, USA). Cells were incubated at $37^{\circ} \mathrm{C}$, in a humidified atmosphere containing 5\% $\mathrm{CO}_{2}$ and $95 \%$ air (Binder, Germany). The medium was changed 24 hours after seeding to remove the non-adherent cells. Thereafter, the culture medium was changed every two to three days. SF cells at passage zero (P0) were grown to $80-90 \%$ confluence and then detached using trypsin (TrypLE TM Express, Gibco). Cells from each of the 5 dogs were reseeded at a density of 5000 cells $/ \mathrm{cm}^{2}$ in T-25 flasks (BD Falcon Primaria ${ }^{\circledR}$ plastic, Biosciences) and for all subsequent analysis sub cultured until passage five (P5).

\section{Colony-forming unit-fibroblasts (CFU-F)}

Passage one SF cells (P1) were seeded in Petri dishes $\left(10 \mathrm{~cm}^{2}\right)$ at a density of 500 cells $/ \mathrm{cm}^{2}$ in the control medium. After 7 days, cells were washed in PBS, fixed in methanol 10 minutes and stained with Giemsa solution. Using an inverted microscope (Olympus CKX41/CKX31) aggregates with $\geq 50$ cells were counted as colonies. Moreover, colonies larger than $1 \mathrm{~mm}$ were counted separately than those smaller than $1 \mathrm{~mm}$. The number of CFU-F was expressed as the percentage of cells seeded but able to form colonies. 


\section{Population Doubling Time (PDT) and expansion fold}

SF cells (P1-P3) were seeded in triplicate in Petri dishes $\left(10 \mathrm{~cm}^{2}\right)$ at a density of $1 \times 10^{4} \mathrm{cells} / \mathrm{cm}^{2}$ in the control medium. Every time the cells were sub cultivated during 3 days to obtain cells in the exponential phases of cell growth. PDT was determined based on the number of seeded cells and the number of cells obtained after trypsin detachment, when the cells reached approximately $70 \%$ confluence. Viable cells were counted using trypan blue. PDT was calculated according to the formula:

$$
\mathrm{PDT}=[\ln (\mathrm{Nf} / \mathrm{N} 0) / \ln (2)] / \mathrm{t}
$$

$\mathrm{Nf}$ was the cell number obtained after detachment, N0 was the seeded cell number, $\mathrm{t}$ was the cultivation period in hours. Cell expansion fold at each week of culture was calculated by the number of cultured cells divided by the number of seeded cells. After cell detachment, the majority of cells were frozen or used for other analyses and one part of the cells was diluted in the new medium and re-seeded. The theoretical total cell expansion fold was calculated by multiplying the expansion fold for each week and the theoretical final cell number was calculated by multiplying P1 cell number with the total cell expansion fold.

\section{Phenotypic characterization of SF cells}

Cells from each of the 5 dogs (P3-P5) were characterized by flow-cytometry using mouse-anti-human CD90 FITC and mouse anti-dog CD34 PE (BD Pharmingen, Biosciences, San Jose, CA, USA). After detachment of adherent cells by trypsin and washing in cold PBS $/ 1 \%$ FCS solution the aliquots containing $1 \times 10^{6}$ cells were incubated with antibodies at $4^{\circ} \mathrm{C}$ for 45 minutes. After washing in PBS $/ 1 \% \mathrm{FCS} / 5 \%$ $\mathrm{Na}$-azide, cells were fixed in $1 \%$ paraformaldehyde and analyzed by CyFlow CL cytometer (Partec, Münster, Germany). Results were expressed as the percentage of positive cells compared with the isotype-matched negative control antibodies on histogram plots.

\section{In vitro differentiation of the SF cells}

Differentiation potential of SF cells from passage 3 to 5 (P3-P5) was investigated by cultivating the cells in commercial adipogenic, osteogenic and chondrogenic differentiation media (Stem PRO media Invitrogen, Carlsbad, CA, USA) at $37^{\circ} \mathrm{C}$ in a humidified atmosphere with $5 \% \mathrm{CO}_{2}$ and $95 \%$ air. For in vitro adipogenic differentiation cells were seeded in triplicate at a density of $5 \times 10^{3} \mathrm{cells} / \mathrm{cm}^{2}$ in 8 -well plates (BD Falcon Culture Slides) in the complete and Stem PRO adipogenesis medium. After 14 days of cultivation accumulation of fat droplets in the cells was shown with Oil Red O staining (Sigma-Aldrich) according to the procedure described: cells were washed in PBS, fixed in 10\% formaldehyde and rinsed with 60\% isopropanol. 3\% Oil Red O solution in $60 \%$ isopropanol was added for $10 \mathrm{~min}$. Stained cells were extensively washed with distilled water to remove any non-specific staining and visualized using an inverted microscope (LEICA DMIL LED, Wetzlar, Germany). 
For in vitro osteogenic differentiation expanded SF cells were seeded in triplicate at a density of $1 \times 10^{4}$ cells $/ \mathrm{cm}^{2}$ in 8 -well plates (BD Falcon Culture Slides) in the complete and Stem PRO osteogenesis medium for 21 days. Some cultures were interrupted the fifth day to determine alkaline phosphatase (AP) activity using Alkaline Phosphatase Detection Kit (Sigma) according to manufacturer's instructions. In order to show calcium deposits formed after three weeks of cultivation, cells were washed with PBS and stained with 2\% Alizarin Red S (Alizarin Red S, pH 4. 2, Sigma-Aldrich) solution for $2 \mathrm{~min}$.

In order to examine the potential for chondrogenesis expanded SF cells were cultured in the control and chondrogenic medium in three-dimensional conditions (3D). To obtain a three-dimensional cell pellet, $5 \times 10^{5}$ cells were centrifuged for $5 \mathrm{~min}$ at $250 \mathrm{x} \mathrm{g}$ in $15 \mathrm{~mL}$ polypropylene tubes. After three weeks of cultivation, pellets were fixed in $10 \%$ neutral formalin for 24 hours, dehydrated through a series of alcohol dilutions, embedded in paraffin and stained with alcian blue to examine the presence of GAGs. The presence of collagen II was determined by immunohistochemistry (IHC).

\section{Concentration of GAG and quantification of DNA}

After papain digestion of cartilaginous pellets, GAG concentration was quantified with the colorimetric method (Biocolor, UK, B1000) and total DNA with the fluorometric assay (FluoReporter ${ }^{\circledR}$ Blue Fluorometric dsDNA Quantitation Kit, Invitrogen, Molecular Probes) on a spectrofluorimeter according to manufacturer's instructions (VICTOR3V 1420-040 multilabel counter, Perkin Elmer Life and Analytical Sciences, Singapore) and emission was measured at $460 \mathrm{~nm}$. Results were expressed as $\mu \mathrm{g}$ GAG/ $\mu g$ DNA.

\section{RESULTS}

Synovial fluid was clear and viscous with protein concentration $(21.1 \pm 10.8 \mathrm{~g} / \mathrm{L})$, TNCC $(0.25 \pm 0.1 / \mathrm{mL})$ and volume of SF within reference intervals $(0.99 \pm 0.5 \mathrm{~mL})$. None of the dogs included in this study had detectable SF SAA indicating no inflammation.

During in vitro manipulation of cells they were viable in a high percentage $(99 \%)$. The average number of cells seeded in P0 was $0.2 \pm 0.05 \times 10^{6}$ (Table 1). Few hours after seeding the cells, they adopted a fibroblastoid morphology and after 5 to 7 days of cultivation they were elongated with multiple processes (Figure 1). In passages P1 to P3 PDT was $31 \pm 10$ hours and expansion fold after 3 sub cultivations was $372 \pm 134$ that theoretically could result in a high cell number suitable for further use (Table 1). At P1, $0.55 \pm 0.05 \%$ of SF cells had the ability to form CFU-F. The majority of CFU-F were large (diameter $>1 \mathrm{~mm}$ ), made of thousands of cells, with high proliferative potential (Figure 1). 
Table 1. Number of cells isolated from the synovial fluid, number of Colony Forming Unit -Fibroblast (CFU-F) and ratio large/small colonies has been shown as well as proliferative characteristics of the seeded cells from P0 to P3 (P-passage)

\begin{tabular}{cccc}
\hline & $\mathrm{P} 0-\mathrm{TCS}\left(\mathrm{x} 10^{6} / \mathrm{mL}\right)$ & $\mathrm{P} 0-\mathrm{TCH}\left(\mathrm{x} 10^{6} / \mathrm{mL}\right)$ & $\mathrm{P} 1-\mathrm{CFU}-\mathrm{F}(\%)$ large $/$ small] \\
\hline $\mathrm{X} \pm \mathrm{SD}$ & $0.25 \pm 0.1$ & $0.65 \pm 0.05$ & $0.5 \pm 0.2[2 / 1]$ \\
$\min -\max$ & $0.15-0.5$ & $0.2-1.4$ & $0.3-0.7$ \\
& $\mathrm{P} 1-\mathrm{P} 3 \mathrm{PDT}(\mathrm{h})$ & $\mathrm{EF}-9$ (days) & TFCN $\left(\times 10^{6}\right)$ \\
$\mathrm{X} \pm \mathrm{SD}$ & $31.3 \pm 9.7$ & $372 \pm 134$ & 223 \\
$\min -\max$ & $19.4-48.0$ & $218-465$ & $/$ \\
\hline
\end{tabular}

TCS - Total cells seeded; TCH - Total cells harvested; PDT - Population doubling time; EF - Expansion fold; TFCN - Theoretical final cell number after 9 days of cultivation
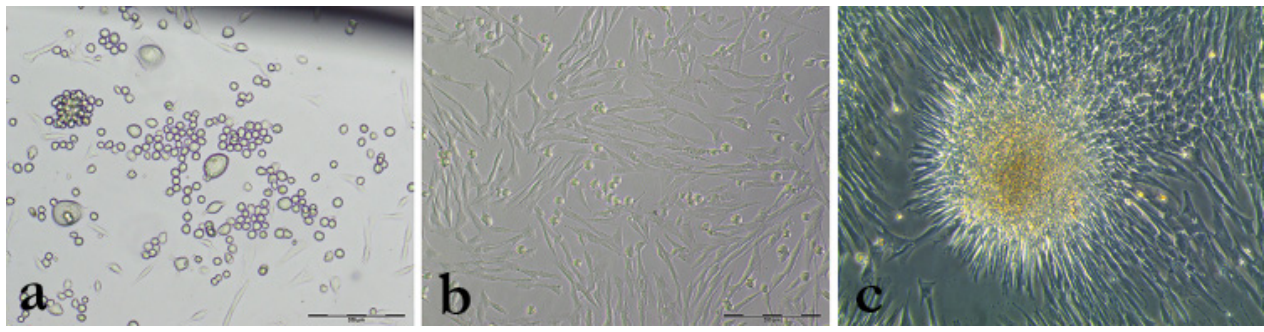

Figure 1. Freshly isolated synovial fluid cell population (a). Twenty-four hours after seeding the initial cell population; adherent cells have become fibroblastoid (b). After 6 to 10 days of cultivation cells have been nearly confluent; occasionaly Colony Forming Unites - Fibroblast have been formed (c). Inverted microscope, bar $200 \mu \mathrm{m}$.

The mean value of CD90 (+) cells from all five dogs (P3 - P5) was $56.43 \pm 10.56 \%$ and for CD34 (-), 0.31 $\pm 0.05 \%$. Percentage of CD90 (+) expanded SF cells was slightly larger than the percentage of CD90 (-) cells (Figure 2a). Expanded SF cells in the same passages were CD34 (-) (Figure 2b). Samples were homogenous regarding CD90 and CD34 expression.
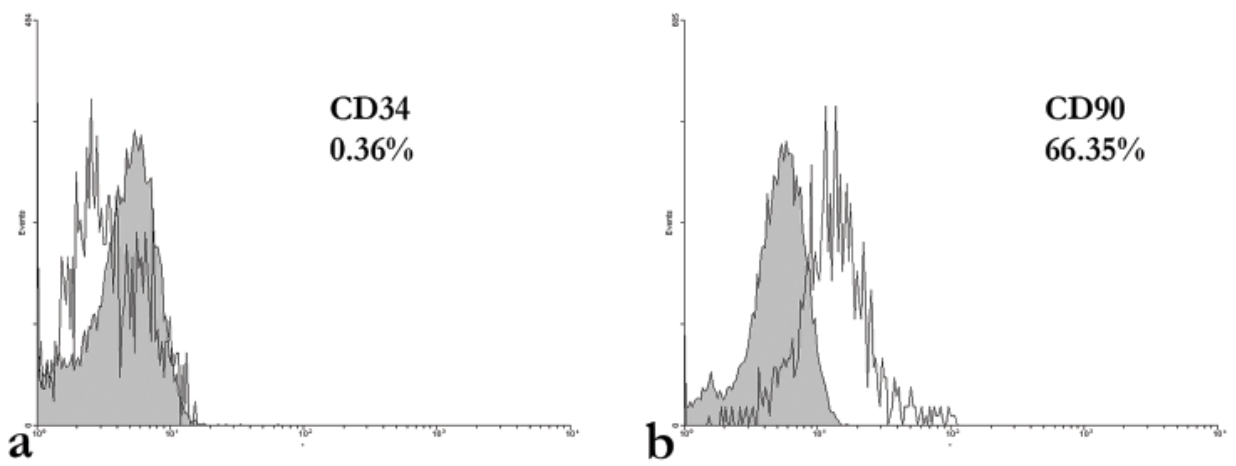

Figure 2. Representative flow-cytometery histograms showing the percentage of cells expressing (non-shaded) CD34 molecules (a) and CD90 molecules (b) compared with isotype controls (shaded). 

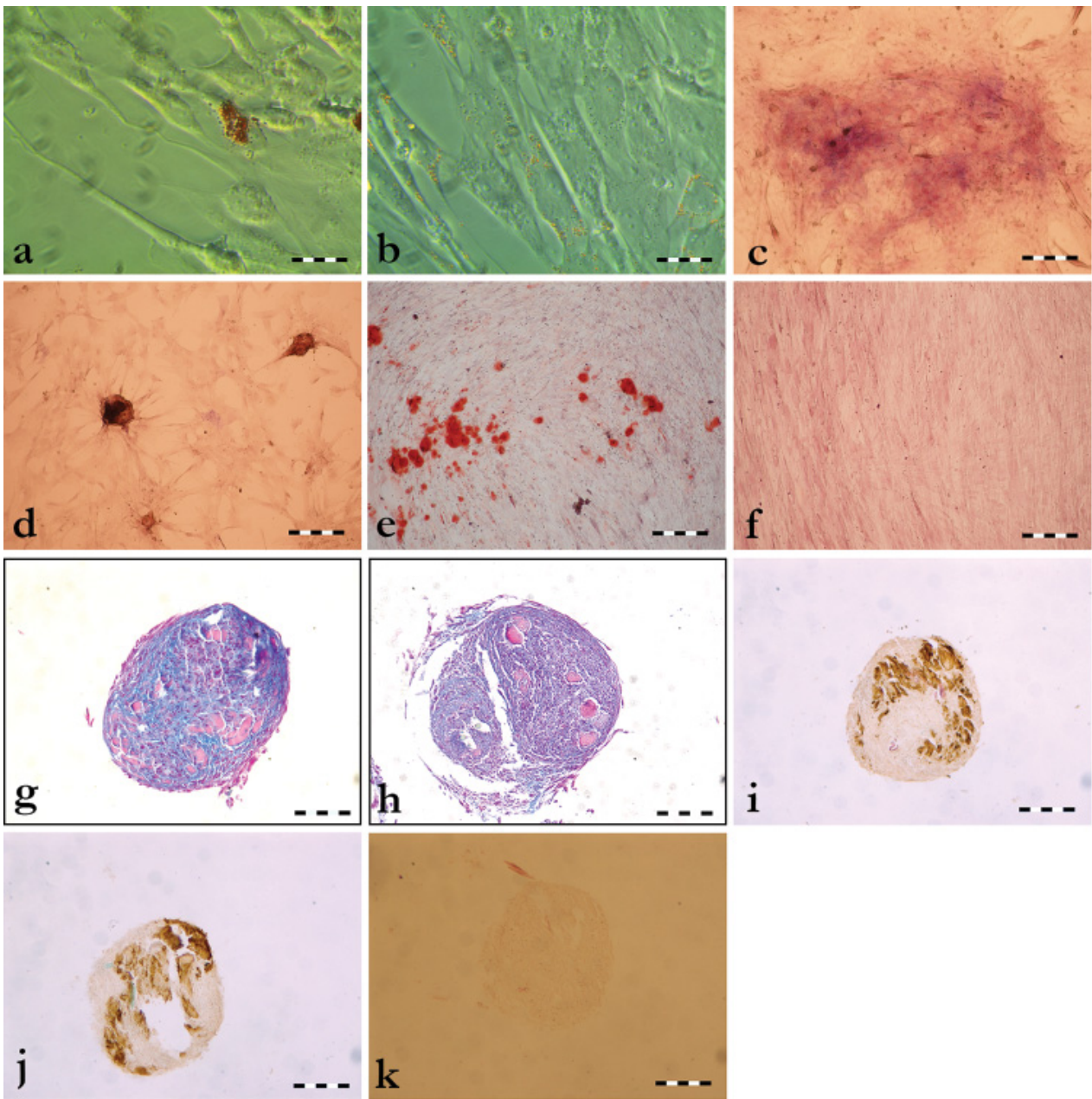

j

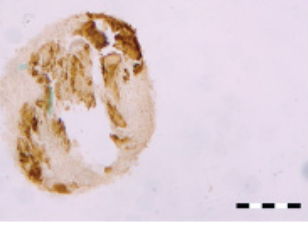

Figure 3. Morphology of differentiated and control synovial fluid cells stained with different techniques. Large lipid droplets in the cytoplasm of individual cells with pre-adipocyte morphology, after 2 weeks in adipogenic medium, Oil red O, inverted microscope, bar $50 \mu \mathrm{m}$ (a). Accumulation of small lipid droplets in the cytoplasm of undifferentiated cells cultivated in the control medium; inverted microscope, bar $50 \mu \mathrm{m}$ (b). Alkaline phosphatase activity, fifth day of cultivation in osteogenic medium (c) and control medium, cytochemistry, bar $200 \mu \mathrm{m}$ (d). Deposits of calcium phosphate stained intensely red with Alizarin red, after three weeks of cultivation in the osteogenic medium (e) no staining in the control medium, bar $500 \mu \mathrm{m}$ (f). Pellets' cartilage-like tissue stained with Alcian blue, after 3 weeks of cultivation in the chondrogenic (g) or control medium, bar $200 \mu \mathrm{m}$ (h); Note the intense blue staining of GAG in the extracelullar matrix (ECM), red nucleus staining and presence of homogeneous pink islands in the ECM (g and h). Collagen type II in the cartilage-like tissue after 3 weeks of cultivation in the chondrogenic medium (i); and control medium (j); immunohistochemistry, bar $200 \mu \mathrm{m}$. Note that the pattern of collagen type II staining follows the pattern of pink islands in Alcian blue staining in both mediums (i). k. Cartilage-like tissue after 3 weeks of cultivation in chondrogenic medium. Collagen type II immunostaining. Representative negative reaction slides. No expression in ECM. 
The major functional characteristic of adult MSCs is their potential to differentiate towards multiple lineages. After two weeks in the adipogenic medium, some of the cells have lost their fibroblastoid morphology and accumulated prominent fat droplets (Figure 3a). In the control medium after 14 days expanded SF cells formed small multilocular fat droplets without signs of change in the cell morphology (Figure 3b). The fifth day of cultivation in the osteogenic medium some of the cells synthesized AP (Figure 3c) and after 3 weeks clusters of cells formed deposits of calcium salts demonstrated by Alizarin red staining (Figure 3e). Expanded SF cells cultured in the hondrogenic and control medium formed pellets with cartilage-like tissue. Histological analysis of pellets cultivated in both, control and chondrogenic medium, stained with Alcian blue showing the presence of GAGs (Figures 3g, 3h). The amount of GAGs was not significantly higher in pellets grown in the control in comparison to the chondrogenic medium $(37.0 \pm 8.7 \mu \mathrm{g} / \mathrm{mL}$ and $45.9 \pm 14.3 \mu \mathrm{g} / \mathrm{mL}$, respectively). Immunohistochemistry analysis of pellets cultured in both conditions revealed intense staining of collagen type II in ECM, in an island-like formation that resembled hyaline cartilage (Figure 3i, 3j). Using histology and IHH techniques no differences in the chondrogenic potential between individual animals were noted.

\section{DISCUSSION}

The main finding of this work is that cells, cultivated from SF of adult young dogs without signs of $\mathrm{OA}$ or inflammation, have a large proliferative potential and the possibility to differentiate toward adipocytes, osteoblasts and chondrocytes, i.e. these cells have typical in vitro characteristics of mesenchymal progenitor cells.

The minimal criteria for defining multi-potent mesenchymal stem/stromal cells were published eight years ago and basically relayed on properties that distinguish connective tissue cells from hematopoietic cells [18]. These include: adherence to plastic (hematopoietic cells are non-adherent cells that grow in suspension culture), in vitro tri-lineage differentiation towards adipocytes, osteoblasts and chondrocytes, and a phenotype that excludes non-differentiated hematopoietic cells (that are CD34+) and leukocytes (that are CD45+), but identifies cells that express CD105, CD90 and CD73. Although many more articles refer their investigation to mesenchymal stem cells and not progenitor cells, one should keep in mind that true stem cells possess self-renewal capability that could be proved only after serial transplantation of the desired cell population [19]. This type of experiment is rarely performed. As we did not have the possibility to test the self-renewal capacity of our cell population, we consider that we cultivated a progenitor cell population and in the following text, we will use the term mesenchymal progenitors.

In this experiment, canine SF cells were tested for a combination of CD34 and CD90, which are frequently used markers for SF cells to screen or to distinguish the non-differentiated hematopoietic from the mesenchymal cell population [17]. Based on CD34 expression, in our culture system, non-differentiated hematopoietic cells 
were not present. On average 56\% of expanded cells expressed CD90 and 44\% did not. The reason for this heterogeneity was that our cultures were polyclonal and probably maintained themselves through divisions of progenitor/precursor cells of synoviocytes type A and/or type B, or even mature synoviocytes. Although not confirmed, the synoviocytes type A are supposed to derive from blood monocytes and synoviocytes type B probably represent the true cells of mesenchymal origin [1]. As it was described previously, blood monocytes could derive from different bone marrow stem/progenitor cells and differentiate to macrophages or even to fibroblastoid cells [20]. We could only speculate that CD90 (-) cells were derived from synoviocytes type A and CD90 (+) cells from synoviocytes type B. Similarly to our finding, culture of SF adherent cells in human patients with RA had two types of cells: fibroblastoid CD90 $(+)$ and macrophage-like CD90 (-) CD68 (+) [21]. Also, CD90 (+) cells have been described to have spontaneous chondrogenic potential in vitro [17]. All stated suggests that although both cell types have the ability to proliferate it would be of great interest to separate both cell types from the very beginning and investigate their properties separately.

In our culture system the PDT was on average $31 \mathrm{~h}$. This is a longer doubling time than we previously have obtained for dental pulp stem cells being on average $24 \mathrm{~h}$ [22]. This observation is in line with the fact that most of SF cells are probably desquamated cells without high proliferative potential and with a slow cell cycle. As our culture system was polyclonal, the obtained PDT reflect the mean of doubling times of all cultured cells. The possibility that among SF cells we raised the true mesenchymal progenitor cells is supported with the fact that on average one cell in 200 cells was CFU-F and the majority of these colonies were large ones. Namely, it was previously demonstrated that the size of colonies is positively correlated with the primitive nature of colony forming cells [23]. Formation of large CFU-F and a fact that expansion was 370 folds for 9 days, support the view that SF of young adult dogs contains mesenchymal progenitors interesting for further investigations.

We also demonstrated that during a two and three week differentiation period, clusters of differentiated adipocytes and osteoblasts formed. The cells that generated these clusters possibly were committed mesenchymal progenitors. Generally, in our culture system adipogenesis was weakly induced, but this was also previously observed during induction of adipogenesis in canine adipose tissue MSCs, possibly due to the type of medium used [24]. On the other hand, according to hierarchical model of in vivo and in vitro bone marrow mesenchymal progenitor differentiation, adipogenic potential is the first to be lost and osteogenic is the last [25]. In our culture system SF cells had a weak AP activity and deposition of calcium salts was scarce comparing to our previous experience with dental pulp stem cells indicating that SF contains less unipotent, or multipotent mesenchymal progenitors [22].

Repair of cartilage is hard to achieve [26,27]. Until present SF fluid has been proposed as a source of cells for cartilage cell therapy in humans, rabbits and pigs $[3,4,28]$. In this experiment, expanded canine SF cells were cultivated in chondrogenic medium 
and after three weeks the pellets contained a cartilage-like tissue. Although cell nuclei were scarce, pellets from both, control and chondrogenic medium had abundant ECM and specific structures (islets) that resembled hyaline cartilage made of collagen type II. No comparable cartilage-like tissue has been described in literature although several papers described high chondrogenic potential of SF cells comparing to adipose tissue and bone marrow [11,29]. Interestingly, synovial fluid progenitors expressing CD90+ from normal but not osteoarthritic joints undergo chondrogenic differentiation without micro-mass culture [17].

Also, the level of GAG was two times higher compared to previous data obtained with dental pulp stem cells (DPSC) [22]. These findings together with data that primary synovial chondromatosis nodules contained cells that spontaneously differentiated along chondrogenic and osteogenic lineages [30] and that the gene expression profiles of chondrogenic progenitor cells and synovial cells are closely related [31] indicate that SM and SF contain cells that could be designated as mesenchymal chondro-osteogenic or chondrogenic progenitors.

\section{CONCLUSION}

Investigations on therapeutic potential of mesenchymal stem/progenitor cells are on the top of scientific objectives worldwide in the last ten years. While abundant data were published on chondrogenic/osteogenic potential of bone marrow and adipose tissue MSCs, SF MSCs have not been largely evaluated in spite of the ease of access and reasonable believe that they possess high chondrogenic potential that could meet the clinical needs for the regeneration of cartilage defects. In this work we have shown that dog SF contains cells with a large proliferative potential and important potential for chondrogenesis for the first time demonstrated by the formation of distinct pure collagen type II islets in cell pellets. In parallel, only few cells demonstrated osteogenic and adipogenic potential that suggests that the majority of SF cells possess chondrogenic potential interesting for further cartilage tissue engineering.

\section{Acknowledgment:}

This work was supported by the grant number 175061 from Ministry of Education, Science and Technologic Development, Republic of Serbia, Bilateral Serbian-French Co-operation "Pavle Savić" for 2012-2013, Short Term Scientific Mission COST Action MP1005 - NAMABIO and ANR Tecsan "Chondrograft".

\section{REFERENCES}

1. Smith MD: The normal synovium. Open Rheumatol J 2011, 5:100-6.

2. Hunziker EB, Rosenberg LC: Repair of partial-thickness defects in articular cartilage: cell recruitment from the synovial membrane. J Bone Joint Surg Am 1996, 78(5):721-33. 
3. Hunziker EB, Kapfinger E: Removal of proteoglycans from the surface of defects in articular cartilage transiently enhances coverage by repair cells. J Bone Joint Surg Br 1998, 80(1):144-50.

4. Hatsushika D, Muneta T, Nakamura T, Horie M, Koga H, Nakagawa Y, Tsuji K, Hishikawa S, Kobayashi E, Sekiya I: Repetitive allogeneic intraarticular injections of synovial mesenchymal stem cells promote meniscus regeneration in a porcine massive meniscus defect model. Osteoarthritis Cartilage 2014, 22(7):941-50.

5. Horie M, Driscoll MD, Sampson HW, Sekiya I, Caroom CT, Prockop DJ, Thomas DB: Implantation of allogenic synovial stem cells promotes meniscal regeneration in a rabbit meniscal defect model. J Bone Joint Surg Am 2012, 94(8):701-12.

6. Horie M, Sekiya I, Muneta T, Ichinose S, Matsumoto K, Saito H, Murakami T, Kobayashi E: Intra-articular Injected synovial stem cells differentiate into meniscal cells directly and promote meniscal regeneration without mobilization to distant organs in rat massive meniscal defect. Stem Cells 2009, 27(4):878-87.

7. Furuzawa-Carballeda J, Macip-Rodríguez PM, Cabral AR: Osteoarthritis and rheumatoid arthritis pannus have similar qualitative metabolic characteristics and pro-inflammatory cytokine response. Clin Exp Rheumatol 2008, 26(4):554-60.

8. Karystinou A, Dell'Accio F, Kurth TB, Wackerhage H, Khan IM, Archer CW, Jones EA, Mitsiadis TA, De Bari C: Distinct mesenchymal progenitor cell subsets in the adult human synovium. Rheumatology (Oxford) 2009, 48(9):1057-64.

9. Nimura A, Muneta T, Koga H, Mochizuki T, Suzuki K, Makino H, Umezawa A, Sekiya I: Increased proliferation of human synovial mesenchymal stem cells with autologous human serum: comparisons with bone marrow mesenchymal stem cells and with fetal bovine serum. Arthritis Rheum 2008;58(2):501-10.

10. Harvanová D1, Tóthová T, Sarišský M, Amrichová J, Rosocha J: Isolation and characterization of synovial mesenchymal stem cells. Folia Biol (Praha) 2011;57(3):119-24.

11. Ando W, Kutcher JJ, Krawetz R, Sen A, Nakamura N, Frank CB, Hart DA: Clonal analysis of synovial fluid stem cells to characterize and identify stable mesenchymal stromal cell/ mesenchymal progenitor cell phenotypes in a porcine model: a cell source with enhanced commitment to the chondrogenic lineage. Cytotherapy 2014, 16(6):776-88.

12. Morito T, Muneta T, Hara K, Ju YJ, Mochizuki T, Makino H, Umezawa A, Sekiya I: Synovial fluid-derived mesenchymal stem cells increase after intra-articular ligament injury in humans. Rheumatology (Oxford) 2008, 47(8):1137-43.

13. Berg RI, Sykes JE, Kass PH, Vernau W: Effect of repeated arthrocentesis on cytologic analysis of synovial fluid in dogs. J Vet Intern Med 2009, 23(4):814-7.

14. Brittberg M, Lindahl A, Nilsson A, Ohlsson C, Isaksson O, Peterson L: Treatment of deep cartilage defects in the knee with autologous chondrocyte transplantation. N Engl J Med 1994, 331(14):889-95.

15. Cook JL, Kuroki K, Visco D, Pelletier JP, Schulz L, Lafeber FP: The OARSI histopathology initiative - recommendations for histological assessments of osteoarthritis in the dog. Osteoarthritis Cartilage 2010, 18:S66-79.

16. Portron S, Merceron C, Gauthier O, Lesoeur J, Sourice S, Masson M, Fellah BH, Geffroy O, Lallemand E, Weiss P, Guicheux J, Vinatier C: Effects of in vitro low oxygen tension preconditioning of adipose stromal cells on their in vivo chondrogenic potential: application in cartilage tissue repair. PLoS One 2013, 8(4):e62368.

17. Krawetz RJ, Wu YE, Martin L, Rattner JB, Matyas JR, Hart DA: Synovial fluid progenitors expressing CD90+ from normal but not osteoarthritic joints undergo chondrogenic differentiation without micro-mass culture. PLoS One 2012,7(8):e43616. 
18. Dominici M, Le Blanc K, Mueller I, Slaper-Cortenbach I, Marini F, Krause D, Deans R, Keating A, Prockop Dj, Horwitz E: Minimal criteria for defining multipotent mesenchymal stromal cells. The International Society for Cellular Therapy position statement. Cytotherapy. 2006, 8:315-7.

19. Bianco P, Robey P, Saggio I, Riminucci M: Mesenchymal stem cells in human bone marrow (skeletal stem cells): a critical discussion of their nature, identity, and significance in incurable skeletal disease. Human Gene Therapy, 2010, 21:1057-1066.

20. Kovačević Filipović M: The Blood is Rich in Different Types of Mesoderm Derived Stem and Progenitor Cells. Acta veterinaria(Beograd) 2014, 64:156-178.

21. Neidhart M, Seemayer CA, Hummel KM, Michel BA, Gay RE, Gay S: Functional characterization of adherent synovial fluid cells in rheumatoid arthritis: destructive potential in vitro and in vivo. Arthritis Rheum 2003;48(7):1873-80.

22. Debeljak Martačić J, Francuski J, Lužajić T, Vuković N, Mojsilović S, Drndarević N, Petakov M, Glibetić M, Marković D, Radovanović A, Todorović V, Kovačević Filipović M: Characterization of deciduous teeth stem cells isolated from crown dental pulp. Vojnosanit Pregl 2014, 71:1-10.

23. Ivanović Z, Bartolozzi B, Bernabei PA, Cipolleschi MG, Milenkovic P, Praloran V, DelloSbarba P: A simple, one-step clonal assay allows the sequential detection of committed (CFU-GM-like) progenitors and several subsets of primitive (HPP-CFC) murine progenitors. Stem Cells 1999,17(4):219-25.

24. Martinello T, Bronzini I, Maccatrozzo L, Mollo A, Sampaolesi M, Mascarello F, Decaminada M, Patruno M: Canine adipose-derived-mesenchymal stem cells do not lose stem features after a long-term cryopreservation. Res Vet Sci 2011, 91:18-24.

25. Muraglia A, Cancedda R, Quarto R: Clonal mesenchymal progenitors from human bone marrow differentiate in vitro according to a hierarchical model. J Cell Sci 2000, 113 (Pt 7):1161-6.

26. Brittberg M, Lindahl A, Nilsson A, Ohlsson C, Isaksson O, Peterson L: Treatment of deep cartilage defects in the knee with autologous chondrocyte transplantation. $\mathrm{N}$ Engl J Med. 1994 331:889-95.

27. Horňák S, Harvanová D, Ledecký V, Hluchý M, Valenčáková-Agyagosová A, Amrichová J, Rosocha J, Vaško G, Švihla R, Petrovič V: Reparation of chondral defects in rabbits by autologous and allogenous chondrocytes seeded on collagen/hyaluronan scaffold or suspended in fibrin glue. Acta veterinaria (Beograd) 2014, 64:61-72.

28. Jones EA, Crawford A, English A, Henshaw K, Mundy J, Corscadden D, Chapman T, Emery P, Hatton P, McGonagle D: Synovial fluid mesenchymal stem cells in health and early osteoarthritis: detection and functional evaluation at the single-cell level. Arthritis Rheumatology 2008, 58:1731-1740.

29. Ichinose S, Muneta T, Koga H, Segawa Y, Tagami M, Tsuji K, Sekiya I: Morphological differences during in vitro chondrogenesis of bone marrow-, synovium-MSCs, and chondrocytes. Lab Invest 2010, 90:210-221.

30. Crawford A, Frazer A, Lippitt JM, Buttle DJ, Smith T: A case of chondromatosis indicates a synovial stem cell aetiology. Rheumatology (Oxford) 2006, 45(12):1529-33.

31. Zhou C, Zheng H, Seol D, Yu Y, Martin JA: Gene expression profiles reveal that chondrogenic progenitor cells and synovial cells are closely related. J Orthop Res 2014, 32(8):981-8. 


\section{POTENCIJAL ZA PROLIFERACIJU I DIFERENCIJACIJU ĆELIJA SINOVIJALNE TEČNOSTI PASA}

FRANCUSKI V Jelena, DEBELJAK MARTAČIĆ Jasmina, RADOVANOVIĆ Anita, ANDRIĆ Nenad, SOURICE-PETIT Sophie, GUICHEUX Jerome, MOJSILOVIĆ Slavko, KOVAČEVIĆ FILIPOVIĆ Milica

Da bi utvrdili da li sinovijalna tečnost (ST) pasa sadrži ćelije koje imaju karakteristike mezenhinskih matičnih ćelija (MMĆ), uzorkovana je ST od 5 mladih pasa (starosti 3.8 \pm 0.9 godina). Sve adherentne ćelije uzgajane su 3 nedelje na $37^{\circ} \mathrm{C}$ u vlažnoj atmosferi sa $5 \% \mathrm{CO}_{2}$, nakon čega je protočnom citometrijom ispitan njihov imunofenotip. In vitro je utvrđeno vreme udvajanja ćelija u kulturi, sposobnost stvaranja kolonija fibroblasta (CFU-F) i potencijal za adipogenezu, osteogenezu i hondrogenezu. U ranim pasažama, ćelije iz ST su se duplirale na svakih $31 \pm 10$ sati, a preračunato je da bi se nakon 3 subkultivacije teoretski mogle umnožiti $372 \pm 134$ puta. CFU-F testom je pokazano da $0.55 \pm 0.05 \%$ ćelija može da formira kolonije. Šezdesetšest posto ćelija je eksprimiralo CD90 molekul, dok CD34 nije bio eksprimiran na ispitivanim ćelijama. Oil Red O bojenjem pokazano je prisustvo masnih kapi u ćelijama uzgajanim $\mathrm{u}$ adipogenom medijumu, dok su depoziti soli kalcijuma bojenjem alizarin crvenim pokazani u ćelijama gajenim u osteogenom medijumu. Ćelijske pelete uzgajane u hondrogenom i kontrolnom medijumu su formirale ekstracelularni matriks bogat glikozaminoglikanima (GAGs) koji su pokazani bojenjem alcijan plavim. Nije uočena razlika u količini GAGs kod ćelija gajenih u hondrogenom i kontrolnom medijumu. Imunohistohemijskim bojenjem pokazano je prisustvo kolagena tipa II u peletema gajenim u oba medijuma. Ćelije ST in vitro imaju adipogeni, osteogeni i hondrogeni potencijal što ukazuje da u ovoj tečnosti postoje mezenhimalni progenitori. Takođe, ove ćelije imaju sponatni hondrogeni potencijal koji dalje treba ispitati zbog moguće primene $u$ tkivnom inžinjeringu. 